\title{
Towards an Appreciation of Ethics in Social Enterprise Business Models
}

\author{
Mike Bull ${ }^{1} \cdot$ Rory Ridley-Duff ${ }^{2}$
}

Received: 2 November 2016 / Accepted: 17 January 2018 / Published online: 29 January 2018

(c) The Author(s) 2018. This article is an open access publication

\begin{abstract}
How can a critical analysis of entrepreneurial intention inform an appreciation of ethics in social enterprise business models? In answering this question, we consider the ethical commitments that inform entrepreneurial action (inputs) and the hybrid organisations that emerge out of these commitments and actions (outputs). Ethical theory can be a useful way to reorient the field of social enterprise so that it is more critical of bureaucratic (charitable) and market-driven (business) enterprises connected to neoliberal doctrine. Social enterprise hybrid business models are therefore reframed as outcomes of both ethical and entrepreneurial intentions. We challenge the dominant conceptualisation of social enterprise as a hybrid blend of mission and market (purpose-versus-resource) by reframing hybridity in terms of the moral choice of economic system (redistribution, reciprocity and market) and social value orientation (personal, mutual or public benefit). We deconstruct the political foundations of charitable trading activities, co-operative and mutual enterprises and socially responsible businesses by examining the rationalities (formal, social and substantive) and ethical commitments (utilitarian, communitarian, pragmatic) that underpin them. Whilst conceptual modelling of social enterprise is not new, this paper contributes to knowledge by developing a theory of social enterprise ethics based on the moral/political choices that are made by entrepreneurs (knowingly and unknowingly) when choosing between systems of economic exchange and social value orientation, then expressing it through a legal form.
\end{abstract}

Keywords Social enterprise $\cdot$ Hybridity $\cdot$ Business ethics $\cdot$ Trading charities $\cdot$ Social businesses $\cdot$ Co-operatives $\cdot$ Utilitarianism $\cdot$ Communitarianism $\cdot$ Pragmatism

\section{Introduction}

Whilst there appears to be broad support for integrating ethical decision-making into social enterprise (SE) governance systems (Ridley-Duff and Bull 2016; Spear et al. 2009) and developing ethical production and consumption practices through 'fair trade' business models such as Fairtrade (see Davies and Crane 2010; Davies et al. 2010; Doherty and Davies 2013; Mason and Doherty 2015), there is a void in the SE literature on the connection between its alleged hybridity and resulting business ethics. We will argue that

Mike Bull

m.bull@mmu.ac.uk

Rory Ridley-Duff

r.ridley-duff@shu.ac.uk

1 Manchester Metropolitan University, Oxford Road, Manchester M15 6BH, UK

2 Sheffield Hallam University, Howard Street, Sheffield S1 1WB, UK this void hides the diversity of ethical, moral and political choices implicit in the labels applied to different SE business models.

Our research question is: "how can a critical analysis of entrepreneurial intention inform an appreciation of ethics in social enterprise business models?'. In developing an answer, we problematise the connection between SE orientations and the business models they create in two ways: (1) by challenging the dominance of the public/private (missionmarket) dichotomy and how this framing limits discussion of SE ethics to the integrity of 'mission'; (2) by linking SE ethics to different motivations to create SEs, the rationalities they generate and the legal forms they take. In short, we examine the connection between the motivations that trigger social entrepreneurship (ethical inputs), and the way moral choices regarding economic exchange, organising principles, legal form and social value orientation produce SEs (ethical outputs).

Whilst prior research has positioned SE hybrids (and social entrepreneurship) as a global movement building a 
social economy distinct from the state and private sectors (Nicholls 2006; Pearce 2003), there remains little analysis within SE research to problematise its ethical commitments (Chell et al. 2016). As depicted in Fig. 1, we see the conception of SE as having a rhetorical front ('trading for social purpose') which is dominant in the framing of SE. However, behind this is a substantive 'deep' back with diverse political foundations that are under-theorised in the field. Despite calls to move beyond definition (Light 2008; Mair and Marti 2006; Nicholls 2006), we still see benefits from problematising the theorisation of SE through the alternative lens of business ethics (Bull et al. 2010; Chell et al. 2016; Dacin et al. 2010, 2011; Dey and Steyaert 2016).

As Roberts (2003) sets out, it is important to distinguish image (rhetoric) and substance (actions). We concur with Daskalaki et al. (2015) that our theorising needs to move to investigating multidisciplinary connections that influence social transformation. They call for new multi-level frameworks. Our response is to connect entrepreneurial intentions to rationalities that inform organisational practices and the legal choices that connect these practices to distinct forms of SE with different political foundations.

Scholars in the field already question whether 'social enterprise' is the Trojan horse for privatisation (Murdoch, 2007), the marketisation of the social economy (Teasdale 2012) or part of a political project to advance neoliberalism into charitable and community-based enterprise (Dey and Steyaert 2016). Such caution is warranted. As several authors have claimed, we need to question the way SE is presented as a revision upholding the spirit of capitalism (Barinaga 2013; Costa and Saraiva 2012; Hjorth 2013). Further, Tedmanson et al. (2012) warn that entrepreneurship as a field of study has been dominated by a pro-market and pro-entrepreneur ideology. Consequently, we agree with Barinaga (2013) that we need to problematise the rationalities that underpin SE, and with Hjorth (2013) that a more public form of entrepreneurship needs recognition in the SE literature. Researchers need to peel away and engage the paradoxes, contradictions and tensions of the entrepreneurial endeavour.

We will argue that behind this rhetorical front there is a substantive back which is given less attention. As Parker and
Thomas (2011, p. 244) 'what counts as critical depends on what counts as dominant'. The mission-market framing of SE is dominant. Whilst Dey and Steyaert (2010) develop a critical response based on 'counter' or 'little' narratives that offset the dominant 'grand' narrative, we see a more substantive back that offers a wider ranging, but coherent, counter perspective. Moreover, as Barinaga (2013) has pointed out, there is more than one social entrepreneurial rationality enacted through the different tools, strategies and methods of management in the case studies she observed. We agree that social entrepreneurial rationalities need further exploration, but also that they need to be considered in light of their political foundations, organisational implications and legal expression. As Daskalaki et al. (2015) contend, new forms of organising and organisation represent social transformations in the way we co-constitute new social realities. We follow their to call to break away from individualistic capitalistic discourses by showing how social entrepreneurship also achieves social transformation through legal models that reflect alternative political and social choices, rather than economic ones.

The substantive back therefore requires more explanation to broaden the concept of SE beyond 'trading for social purpose'. To do this, we grapple with the paradoxes, contradictions and tensions in the dominant discourse.

We identify three disconnections that open up the substantive back, which require more theorising:

1. How political foundations differ across the breadth of SE forms;

2. How conceptualisations of SE (community interest companies, trading charities, co-operatives, mutuals, community benefit societies) link political foundations to ethical commitments;

3. How a theory of social enterprise ethics can inform the development of the field.

This critical approach, based on an alternative way of seeing, contributes to a more critical entrepreneurship literature (Barinaga 2013; Daskalaki et al. 2015; Hjorth 2013; Steyaert and Hjorth 2005). As Ogbor (2000, p. 607) argues: '...deconstruction of entrepreneurial discourse enables us
Fig. 1 Conceptualising the challenge of social enterprise ethics

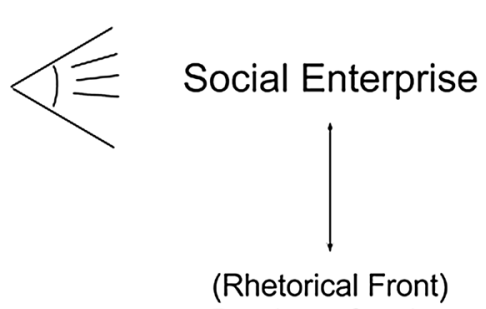

Dominant framing
1 - Charitable Trading Activities (CTAs)

2 - Cooperative and Mutual Enterprises (CMEs)

3 - Socially Responsible Businesses (SRBs)

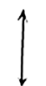

(Substantive Back)

Diverse political foundations 
to become resistant, rather than assenting, spectators and readers of entrepreneurial texts. Significantly, it enables us to examine those binaries that have been supplemented and/ or silenced in the discourse on entrepreneurship'.

We explore the silences created by the dominant missionmarket discourse on SE to build on Hjorth's (2013) argument that we need a more intensive discussion of the social, and Steyaert and Hjorth's (2005) argument that we need a more thoughtful elaboration of the relationship between entrepreneurs and society. We expose the first disconnection (1) by considering differences in political, moral and ethical commitments that arise out of three different rationalities (formal, social and substantive). This eschews the oversimplified public-private (mission-market) dichotomy in SE by favouring an alternative analysis based on hybridities that occur when moral choices are made between economic systems (redistribution, reciprocity and market) and social value orientation (personal, mutual and public benefits). As a result, we tackle the second disconnection (2) by reorienting the field so that it considers differences in the ethical commitments that stem from charitable trading, from cooperation and mutuality and from socially responsible business (Fig. 1). Specifically, we will argue that three core approaches to SE have an associated rationality and legal foundation that produces different ethical outcomes: hybrid (i) charitable trading activities (CTAs) that are influenced by the formal rationality of fixed charitable or social objects; hybrid (ii) co-operatives and mutual enterprises (CME) are guided by social rationality in mutual associations and cooperative action, and; hybrid (iii) socially responsible businesses (SRBs) that are outcomes of social entrepreneurs' substantive rationality (Ridley-Duff and Bull 2016). This approach enables us to tackle the final disconnection (3) to frame a response to the special issue of the Journal of Business Ethics on outstanding ethical issues in SEs (see Chell et al. 2016). We set out new lines to start new conversations.

Whilst wrestling with the definitional tensions within the field of SE is not new, extending the debate to rationalities and ethics adds to a growing body of papers taking a more critical perspective. By showing that ethical commitments are rooted in social and political choices that produce different types of SE, the field can broaden its focus and move away from seeing management as a series of technical choices to a more critical understanding of the moral and political choices that social entrepreneurs make when they institutionalise their organising through their choice of legal form (Barinaga 2013; Wray-Bliss 2009). We contribute to CMS through unsettling the dominant mission-market SE discourse on hybridity in favour of a more nuanced analysis that exposes the plurality of choices available and the new forms of organising that actualise social transformations (Daskalaki et al. 2015).
To build our argument, we have divided the paper into four sections. In the first section, we explore the SE literature with the specific aim of critiquing and contextualising hybrid models to highlight the dominance of a discourse that offers a choice of public, social and private enterprise. We then position our argument as an alternative worldview rooted in a choice between associative (CTAs), cooperative (CMEs) and responsible (SRBs) social entrepreneurship. Secondly, we contextualise our paper within the broader field of business ethics and pinpoint the gap in the literature we contribute to. This sets the scene for a section that outlines formal, social and substantive rationality and examines how they link to conceptualisations of SE. Lastly, we link our discussion of ethics to a meta-theory of economic choices and social value orientations (based on Dreu and Boles 1998; Polanyi 2001) to show how the various motives to action (ethical inputs) produce a diversity of organising principles and outcomes (ethical outputs). In our conclusions, we highlight our contribution by arguing that the diversity of SE itself is linked to moral and political choices regarding economic exchange and social value creation (compare Bull et al. 2010).

\section{Conceptualising Social Enterprise}

At a grassroots level, SE in the UK initially gained its strongest foothold within the co-operative movement and community regeneration sector (Ridley-Duff and Southcombe 2012; Teasdale 2012). Prior to 2001, the focus was on building a broad movement of employee-owned businesses (EOBs) and philanthropically minded community benefit societies funded by community share issues (Brown 2004, 2006). By late 1997, a coalition of co-operatives and co-operative development agencies had formed Social Enterprise London. As regional links developed, a national body - the Social Enterprise Coalition (SEC), was created to lobby for cooperatives, social firms, trading charities, community and employee-owned businesses.

As time passed, and particularly after a UK government consultation involving charities and voluntary groups, the co-operative origins of the SE movement in the UK became obscured by a strengthening (US-dominated) discourse on earned income and innovation in charities and public services (Ridley-Duff 2007, 2008; Somers 2013; Teasdale 2012). A gradual move from redistributive philanthropy to forms of market-action is also found in some early UK research (Amin et al. 1999; Westall 2001). The effect was to raise the profile of social businesses as a policy option through joint action by governments and private charitable foundations or through partnerships with 'responsible' corporations. 
In early SE discourse, as highlighted by Pearce (2003, p. $34)$, there was an underlying assumption that SE is an ethical activity: 'The purpose of social enterprises is to contribute to the common good, to benefit society and more widely, the planet. Specific objectives will fit within this overarching sense of social purpose'. In 2002, the UK Government published its strategy for SE (DTI 2002). This outlined a new era and political framework for the development of SE in England and Wales. As part of the positioning of the sector, the strategy crafted a definition still used widely today. It read: 'A social enterprise is a business with primarily social objectives whose surpluses are principally reinvested for that purpose in the business or in the community, rather than being driven by the need to maximise profit for shareholders and owners'. The strategy itself recognised various hybrid organisational forms under the SE umbrella that are (weakly) recognised in the official definition. Likewise, there is no mention of ethics in either the definition or the entire 81-page strategy. Given the claim that ethics and morality are at the heart of SE (Bull et al. 2010) combined with a rhetorical proposition that SE is about 'trading for a social purpose' why is ethics missing from policy discussion?

The dominant discourse on SE emphasises its hybrid organisational form, or forms, blending mission and market logics that are coined variously as 'businesses with social purpose' or 'in business for good' (Billis 2010; Mason and Doherty 2015). As Defourny and Nyssens (2010, p. 44) note, in agreement with Pearce (2003), 'for all schools of thought, the explicit aim to benefit the community or the creation of social value is the core mission of social entrepreneurship and social enterprises'. This high moral ground was expressed in the first version of the Social Enterprise Mark (SEM) by featuring a halo above the words 'social enterprise' (Ridley-Duff and Bull 2016).

This discourse has shaped conceptual models of SE. Table 1 shows theoretical framings that we have used in

Table 1 Analysis of enterprise orientations

\begin{tabular}{|c|c|c|c|c|c|c|c|c|}
\hline \multicolumn{9}{|c|}{$<$ - Philanthropic Enterprise Orientation - Commercial Enterprise Orientation - > } \\
\hline Theorist & \multicolumn{8}{|c|}{ (SE) Business Model } \\
\hline Dees $(1998)$ & \multicolumn{2}{|c|}{ Mission driven } & \multicolumn{4}{|c|}{ Mission and market driven } & \multicolumn{2}{|c|}{ Market driven } \\
\hline Conaty (2001) & Charity & & \multicolumn{3}{|c|}{ Co-ops and mutuals } & \multicolumn{2}{|c|}{ Social business } & $\begin{array}{c}\text { Small } \\
\text { businesses }\end{array}$ \\
\hline Westall (2001) & \multicolumn{3}{|c|}{ No owners (Trustees) } & \multicolumn{3}{|c|}{$\begin{array}{l}\text { Multi-stakeholder } \\
\text { governance / multiple } \\
\text { owners }\end{array}$} & \multicolumn{2}{|c|}{ Outside shareholders } \\
\hline Cornforth (2003) & \multicolumn{3}{|c|}{$\begin{array}{l}\text { No owners, trustee-controlled and } \\
\text { governed } \\
\text { Compliance/rubberstamp model }\end{array}$} & \multicolumn{3}{|c|}{$\begin{array}{c}\text { Member-owned, controlled } \\
\text { and governed } \\
\text { Democratic model }\end{array}$} & \multicolumn{2}{|c|}{$\begin{array}{l}\text { Investor-owned, controlled } \\
\text { and governed } \\
\text { Agency theory }\end{array}$} \\
\hline Alter (2004) & $\begin{array}{l}\text { Traditional } \\
\text { non-profit }\end{array}$ & \multicolumn{3}{|c|}{$\begin{array}{l}\text { Non-profit with } \\
\text { income generating } \\
\text { activities }\end{array}$} & \multicolumn{2}{|c|}{ Social enterprise } & $\operatorname{CSR}$ & $\begin{array}{l}\text { Traditional } \\
\text { for-profit }\end{array}$ \\
\hline $\begin{array}{l}\text { Ethics and Rationality } \\
\text { (Wagner-Tsukamoto } 2005 \text {, } \\
2007 \text {; Bull et al 2010) }\end{array}$ & \multicolumn{3}{|c|}{$\begin{array}{c}\text { Level } 5 \\
\text { Active blended moral agency } \\
\text { supported by formal rationality }\end{array}$} & \multicolumn{4}{|c|}{$\begin{array}{c}\text { Level } 3 \text { and } 4 \\
\text { Active moral agency rooted in } \\
\text { social and substantive rationality }\end{array}$} & $\begin{array}{l}\text { Level } 1 \text { \& } 2 \\
\text { Unintended } \\
\text { moral agency }\end{array}$ \\
\hline Bull $(2008,2015)$ & \multicolumn{3}{|c|}{ Charity law } & \multicolumn{3}{|c|}{ Society law } & \multicolumn{2}{|c|}{ Company law } \\
\hline Hjorth (2013) & \multicolumn{5}{|c|}{ Socialising } & \multicolumn{3}{|c|}{ Economising } \\
\hline Laasch and Conway (2015) & \multicolumn{2}{|c|}{ Business foundation } & \multicolumn{4}{|c|}{ Social enterprise } & $\begin{array}{l}\text { Responsible } \\
\text { business }\end{array}$ & $\begin{array}{l}\text { Irresponsible } \\
\text { business }\end{array}$ \\
\hline \multirow[t]{2}{*}{$\begin{array}{l}\text { Defourny and Nyssens } \\
\text { (2016) ICSEM Project. }\end{array}$} & \multicolumn{2}{|c|}{$\begin{array}{l}\text { Entrepreneurial non-profits } \\
\text { (ENPs) }\end{array}$} & \multicolumn{3}{|c|}{$\begin{array}{c}\text { Social co-operatives } \\
\text { (SC) }\end{array}$} & \multicolumn{2}{|c|}{$\begin{array}{c}\text { Social businesses } \\
\text { (SB) }\end{array}$} & \\
\hline & \multicolumn{7}{|c|}{ Public Sector Social Enterprise (PSSE) } & \\
\hline Ridley-Duff and Bull (2016) & $\begin{array}{l}\text { Charitable } \\
\text { activities }\end{array}$ & $\begin{array}{l}\text { CTA } \\
\text { (Charita } \\
\text { tradin } \\
\text { activiti }\end{array}$ & & & $\begin{array}{l}\text { CMEs } \\
\text { perative an } \\
\text { l enterprise }\end{array}$ & & $\begin{array}{l}\text { SRBs } \\
\text { (Socially } \\
\text { esponsible } \\
\text { ousinesses) }\end{array}$ & $\begin{array}{l}\text { For-profit } \\
\text { business }\end{array}$ \\
\hline
\end{tabular}


both teaching and research, all of which appear unequivocally as a spectrum of orientations that range from philanthropic to commercial enterprise. Prior to the launch of SE in the UK, Dees (1998) in the USA and Pestoff (1998) in Europe were theorising a trend towards more commercial approaches in the non-profit sector. Pestoff (1998) outlines European hybridity thinking and what he calls the welfare mix between state and enterprise orientation. He draws on Polanyi (2001, [1944]) to conceptualise SE as a combination of various actors (state, community and for-profit companies), deploying various logics of action (public, non-profit, private for-profit, informal and formal) to engage in different types of economic exchange (redistribution, reciprocity and market). Unlike 'third sector' conceptualisations of SE in the UK aligned to 'community', Pestoff places it firmly at the intersections between community-based, profit-making and public-benefit activities.

Dees in the USA warned of the cultural challenges to non-profits from the operational strategies required by a change of enterprise orientation. Dart (2004) concurs that a 'business-like' hybrid enterprise orientation modifies morality in virtuous organisations and that this results in a cultural shift towards a neoconservative, pro-market agenda. Dees (1998) visually represents three enterprise orientations: (1) charitable type, mission-driven, non-profit organisations; (2) market-driven, profit-seeking organisations; and (3) mission and market-driven hybrid enterprise orientation (Table 1).

Interestingly, Dees introduces the dichotomy of 'appeal to goodwill' and 'appeal to self-interest', which opens up the link between SEs and business ethics. An appeal to goodwill invites action that is philanthropic and redistributive, which we discuss later by contrasting it with an egoistic, neoliberal (market) orientation.

Through a comparison of Dees (1998), Hjorth (2013) and Laasch and Conway (2015), we can observe that a commercial orientation is theorised as internal value creation ('economising') combined with egoism (on the right of Table 1). This is presented as the opposite of external value creation ('socialising') and philanthropy (on the left of Table 1).

Laasch and Conway's model highlights the demarcation between the different value propositions of organisations. They conceptualise ('irresponsible business') which pinpoints an internal enterprise orientation combined with an egocentric mission. This is aligned with Dees's 'purely commercial' orientation. 'Irresponsible' business (Laasch and Conway 2015) might not necessarily be breaking the law (e.g. selling illegal substances like cocaine), but it could include clothing manufacturers that exploit child labour or retailers that avoid paying tax in countries where they trade. The broad generalisation that commercial businesses are irresponsible is treated with caution by other authors. The work of Wagner-Tsukamoto $(2005,2007)$ is subtler because it suggests that the outcome of market processes (consumer needs met, employment opportunities created, trading) increases living standards, which has some virtue in terms of a greater good for society. At level 1, Wagner-Tsukamoto proposes that business activity passively satisfies some unintentional level of moral agency by virtue of 'doing' business. Thus, the unscrupulous activities of clothing manufacturers using child labour in their supply chains do have some level of moral legitimacy and ethical capital in Wagner-Tsukamoto's eyes if they are contributing to 'rising living standards and rising welfare in society' (2007, p. 210).

Laasch and Conway's (2015) next conceptualisation ('responsible business') is taken to include those commercial organisations that practice corporate social responsibility and/or address UN sustainable development goals. For Wagner-Tsukamoto (2007), this enterprise orientation covers two levels-level 2 ('passive, intended moral agency') and level 3 ('active, intended moral agency') (2007, p. 210). At level 2, there is an ethical commitment to strategically doing the minimum, staying within the law but not creating value for key shareholders beyond what Carroll (1991) refers to as legal and economic responsibilities. Following Friedman (1970), enterprise orientations observe the injunction to stay within the rules of the game. For the previously mentioned clothing manufacturers exploiting child labour, it would be within the 'rules of the game' to abide by a country's policy on labour age, even if it is lower than in other parts of the world (see Fisher and Lovell 2006 for the case of Adidas Soloman). At level 3, Wagner-Tsukamoto identifies where stakeholder considerations are accommodated—so long as they do not override shareholder interests. Intended moral agency is played out in organisations that embrace a neoliberal sustainability agenda.

However, Laasch and Conway's next conceptualisation ('social enterprise') is positioned as an enterprise orientation with more of an external than internal orientation towards value creation and mission, going beyond the selfinterest inherent in neoliberalism. The challenge here is the positioning of co-operatives as SEs, because co-operatives might superficially display a more internal than external orientation, or be associated with Dees's mission and market 'mixed motives'. As seen in Table 1, the positioning of co-operatives is, however, recognised explicitly by Conaty (2001), Westall (2001), Cornforth (2003), Defourny and Nyssens (2016) and Ridley-Duff and Bull (2016). Lastly, Laasch and Conway discuss philanthropic organisations with an external value orientation ('business foundations'), similar to Dees's 'purely philanthropic' type and Hjorth's 'socialising' entrepreneurship with a public ethos.

Alter (2007) makes a similar argument to Dees, Laasch and Conway. She positions enterprise orientations along a spectrum to distinguish different business models. She highlights a step change between those on both the social and economic value creation ends of the economy. Ethics 
are alluded to here, inasmuch as Alter posits that socially responsible businesses follow sustainability strategies under the ideology of 'doing well by doing good' — good taken to mean a public good based on utilitarian ethical reasoning. Bull et al. (2010) also furthered Wagner-Tsukamoto's theorem by plotting a fourth and fifth level of ethical capital over Alter's model. Levels 4 and 5 occur on the social value side of Alter's diagram, with level 4 titled 'intended blended value' that combines 'social' and 'economic' outcomes, and level 5 which goes beyond balancing to give preference to 'social' outcomes. The distinction between 'non-profit with income generating activities' and 'social enterprise' in Alter's model is interesting because it opens up space to consider different enterprise orientations in the social value creation side of the economy.

Conaty (2001) also notes these differences by distinguishing 'the social enterprise way' as 'the ethical path between charity and commerce'. Conaty suggests SE hybridity ranges from the trading activities of charities at one end to cooperative and mutual societies at the other. He also refers to the success of SE being down to 5Ms-one of which is moral motivation (the other four being; markets, management, mouth and money). Just as Wagner-Tsukamoto opens up nuanced differences amongst the ethical differentiators of private companies, Alter, Dees and Conaty start of offer evidence of ethical differentiation between types of SE. Of interest here is the way Conaty draws attention to an ethical path as well as the two enterprise orientations labelled 'social business' and 'co-ops and mutuals'. If we add Alter's label, we arrive at three hybrid forms of SE: (1) 'non-profits with income generating activities'; (2) 'co-ops and mutuals', and; (3) 'social businesses'.

In Bull (2015) and Ridley-Duff and Bull (2016), the hybrid logics of SE are explored to arrive at the same three forms of SE. They both frame SEs in three ways: hybrid (i) CTAs constituted in charity law; hybrid (ii) CMEs constituted in society law; and hybrid (iii) SRBs constituted in company law. This aligns with the latest global research project (ICSEM) led by Defourny and Nyssens (2016). The ICSEM project also separates organisational types into distinct hybrids: (1) public sector social enterprises (PSSE); (2) entrepreneurial non-profits (ENP); (3) social co-operatives (SC); and (4) social businesses (SB). This research draws heavily on Spear et al. (2009) who first outlined these four types. Bull (2015), however, challenges the concept of PSSE because each SE is constituted through one of the other legal forms. Put simply, all PSSEs choose between CTA, CME or SRB enterprise orientations (so we represent PSSEs in Table 1 as spanning the other three choices). This reading of the literature concurs with earlier work by Westall (2001) and Cornforth (2003) who also saw three configurations that align with the same distinctive SE types (CTAs, CMEs and SRBs).
Based on this review, we settle on three configurations of hybridity (highlighted in grey in Table 1). In the next section, we focus on the rationalities and ethical propositions of these three types. We firstly position ourselves in relation to the literature on business ethics, then set out the differences between formal, substantive and social rationality. We argue that each rationality changes the criteria for making moral choices, leading to divergent ethical commitments that influence each approach to SE.

\section{Ethics and Rationality}

Business ethics is a contested field polarised between those that seek to prescribe and describe ethics and those that see little value in studying it at all (Parker 1998a, b). Parker (1998a, b) contends that academic study of ethics cannot escape prescriptions of various 'authorities' by turning its attention to the 'more solid terrain of description' because there is no consensus about the nature of being. Faced with the conundrum of not being able to reach a consensus on what it is to be ethical, Parker points to the 'turn' in the works of Derrida, Foucault, Giddens and Habermas on the way social norms impact judgment. This foregrounds epistemology, ways of knowing, to give rise to the study of business ethics as a study of the political 'foundations' on which ethical commitments are socially constructed.

Parker's assumptions are challenged by Anthony (1998) who contends that business ethics does not derive from the on-high proclamations of political institutions but out of everyday interactions between workers and managers. He cites Selznick's (1992, p. 19) view that moral choices 'are not elements of an external ethic brought to the world like a Promethean fire. They are generated by mundane needs, practical opportunities and felt satisfactions'. Based on Selznick's statement, we contend that social enterprise development, indeed all business development, is rooted in everyday moral choices, satisfactions and opportunities we seek for ourselves and others, and our choice of whether to direct our own labour or allow others to direct it for us. These starting points are shown in Fig. 2.

Rhodes et al. (2010a, b, p. 536) claim that it is possible to establish empirically that "ethics in practice" [is] embedded in the mundane activities of organising and managing'. The 'organising' and 'managing' that interests us are those that social entrepreneurs generate through their SEs as they confront dilemmas in their relationships with others (WrayBliss 2009). We have circled these in Fig. 2: (1) motivations to help others to help oneself; (2) the desire to help others without exploiting oneself, and; (3) the motivation to self-direct one's own efforts to help others. As Wray-Bliss (2009) sets out, critical ethics arises out of reflecting on the impact of our relationships with others, our responses to 
Fig. 2 A matrix of everyday interactions

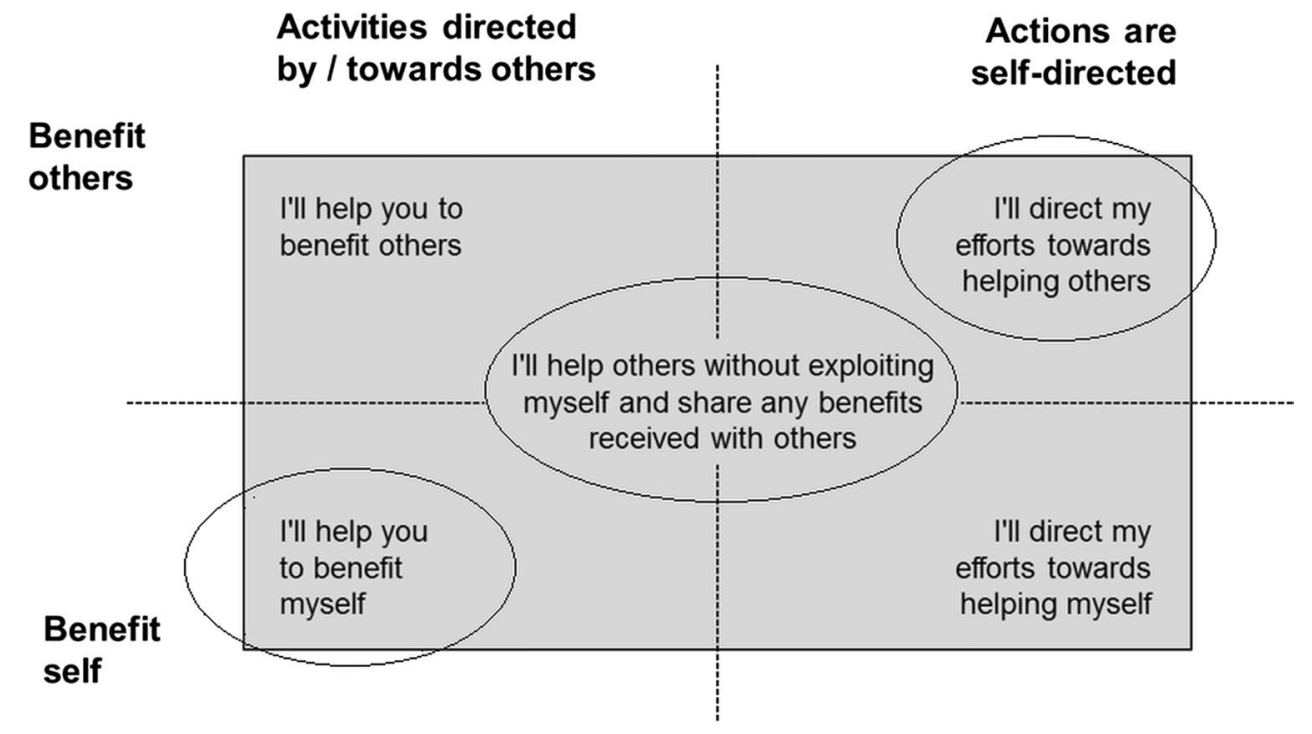

Actions are

self-directed their demands, the extent to which we distant ourselves from them or, alternatively, feel a sense of responsibility to or for them.

Before we can build on Fig. 2, we need to set out our views on three rationalities (formal, substantive and social) and discuss how they link to our choice of SE theories (Table 1). Barinaga (2013) challenges SE scholars to acknowledge the political implications of social entrepreneurial rationalities. We do this by going beyond Barinaga's choices (economic, discursive and community) to consider the political and philosophical origins of formal, substantive and social rationality.

Formal rationality was advanced by Weber (1978, p. 656) as a 'logically clear, internally consistent, and, at least in theory, gapless system of rules' that provides the legal foundations for advanced societies. Within this system, decision-making is intended to proceed based on predictability, applying logic to derive abstract principles that bring about consistency when making judgements. Moreover, these abstract principles are enforced through the application of rules based on predetermined judgement criteria (Feldman 1991). Legal frameworks based on formal rationality are necessarily controlled by an elite. Weber argued that (when making decisions) it was best to exclude 'external interference' on the basis that it could corrupt the process of applying abstract principles in the interpretation of rules. As Shamir (1993) notes, this led Weber to devalue knowledge derived from practice. Weber not only favoured a scholarly approach to rule making, but also that the resulting rules should be enforced in a way that shielded rule enforcers from the influence of others (particularly those engaged in practice).

A clear link with Weber's formal rationality persists today in 'best practice' guidelines adopted by charities and related hybrid SEs with top-down approaches to governance.
Throughout the 1990s and 2000s, private sector guidance on corporate governance reinforced the idea that governors and executives should protect their independence by favouring outside directors and trustees. Within this system, employees who are hired to enact the rules have little or no part to play in making them, whilst senior managers and trustees/directors make and enforce them. Whilst Weber distinguished 'rigid' and 'logical' applications of formal rationality (Shamir 1993), he sought to avoid alternative rationalities that considered 'ethical imperatives, utilitarian and other expediential rules and political maxims' (Weber 1978, p. 657).

This alternative, which he regarded as substantive rationality, eventually came to the fore in the USA when Dewey, Pierce, James, Holmes and Gray supported the New Deal in the 1930s (Shamir 1993). This challenged the dominance of formal rationality by attacking the privileged position of scholarly elites and capital owners. It also provided a way for democrats to challenge the normative influence of formal rationality which concealed 'the unequal distribution of economic and political power [...] behind a veil of objective science' (ibid., p. 49).

Substantive rationality differs through its focus on the goals of rational actors and the environment in which they are realised (Simons, 1978). In place of abstract principles decided a priori by an elite, substantive rationality focuses on contextually appropriate decision-making in each environment. As Shamir (1993) points out, Weber eschewed this type of rationality as the basis for a legal system. In doing so, he failed to appreciate the value of substantive rationality for studies of goal-directed entrepreneurs. More broadly, the logics of substantive rationality present a challenge to the idea that a universally applicable system of rules based on formal rationality can produce ethical outcomes in practice, because social contexts and norms vary so widely. 
Substantive rationality would hold that the best decisions are local, not universal, and that a range of decisions may be adequate for a given situation. The 'best' decisions will also vary across time and space.

Connecting substantive rationality to social entrepreneurship is straightforward because the latter is rooted in an action-orientated approach to revealing, reframing and challenging inequitable distributions of power and wealth in a specific community (Martin and Osberg 2007). Moral judgements rest on whether the motivations of social entrepreneurs are practically adequate for a given context. For example, the moral claim that Yunus's (2007) concept of social business is 'better' is based on the practical adequacy of the Grameen Bank's role in mitigating rural poverty in Bangladesh. Justification does not depend on an appeal to precedents and a priori abstract principles, but on the outcomes achieved for people. As Shamir (1993) describes, this aligns substantive rationality with pragmatism because ethics are made and remade in the context of practicethe 'mundane' everyday decisions referred to by Anthony (1998), not a priori abstract reasoning advanced by Weber. Seen in this light, social entrepreneurship is the application of pragmatism rooted in the substantive rationality of the social entrepreneur. It is triggered and sustained by sensitivity to local political and social issues, and its ethical salience is linked to the outcomes achieved.

The criticism that pragmatism promotes expediency rather than ethical behaviour (based on Weber's notion of abstract principles) is rejected by Haack (1976, p. 232) on the basis that counter-arguments depend on an 'inadequate understanding of the theory [of pragmatism]'. Critics place too much emphasis on pragmatism's 'practical utility' criterion and ignore its stated commitments to coherence and correspondence with an objective reality. Haack (1976) defends pragmatism by arguing that formally rational systems cannot sustain ethical outcomes in practice because rules abstracted from reality (i.e. that neither correspond to nor are coherent with local realities) have less practical utility because they are less able to accommodate (and be responsive to) the moral choices that occur in different social contexts.

Our view, however, is that both formal and substantive rationality are vulnerable to the criticism made by Simons (1978) that they are blind to the discipline of (social) psychology. Whilst substantive rationality might account for the 'learning by doing' approach of individual social entrepreneurs, it cannot account for SEs that emerge from collective action. We need a more critical ethics (Wray-Bliss 2009, p. 273) to wrestle with 'the multitude of unique met and unmet others, each of which have the same call upon [us]'. The field of SE does not just concern itself with products and services, but also the contribution of SEs to the quality of human relationships within a community. It is for this reason that international definitions and laws identify the need for governance systems that enable people affected by decisions to contribute to making them (Defourny and Nyssens 2016; Restakis 2010; Ridley-Duff 2015). Moreover, Laville and Nyssens (2001) have long argued that one of the primary 'products' of SE is social, not economic, capital. Creating the social capital that sustains a community requires the establishment of social networks where relationship quality improves and levels of trust increase.

The rationality that applies in this case is social, not substantive (Ridley-Duff 2008; Ridley-Duff and Bull 2016). Social rationality occurs when decision-making is guided by considerations of whether to form, develop or maintain relationships for their own sake (rather than an instrumental purpose). From a socially rational perspective, decisions would be taken (or not taken) based on whether the person making the decision wanted to disrupt or preserve friendship networks, business relationships and family ties. In terms of its ethics, it is the rationality closest to critical ethics. It concerns itself wholly with the relationship between selves and others (Wray-Bliss 2009), and the rationales we develop for more intimate or more distant relationships. Social rationality, therefore, is qualitatively different to formal and substantive rationality in that decisions are made based on their potential to shape, change, preserve or end social relationships.

The connection to CMEs is easy to make through an examination of its guiding principles. Six of the seven cooperative principles (open membership, democratic control, economic participation, autonomy, inter-cooperation and concern for community; see Birchall 2012) guide relationships rather than missions, products or services. They guide the relationships between individual members, members and their enterprise, and between their enterprises and the wider community. The relationship focus can appear in the mission statements of co-operatives. For example, Seward Community Co-operative's website suggests they commit to 'sustaining a healthy community that has: equitable economic relationships, positive environmental impacts and inclusive, socially responsible practices'. The principles establish a norm of thinking about the social aspects of organising, tackling social exclusion and promoting community participation (associational life) as an integral part of business (see Scott-Cato et al. 2008).

We can link these three rationalities to SE business models. In CTAs, the commitment to social or charitable aims dominates. The legal framework requires trustees/directors to take decisions that advance specific 'objects'. This not only accounts for Cornforth's 'Compliance'/'rubber stamp' governance mode and Agency Theory for command and control, it also inclines trustees/directors towards formal rationality (framed by utilitarian ethics). Trustees/directors of charities, in law, are judged as having a conflict of interest 
if they combine practice (working) with trusteeship (governing). In Weberian terms, trustees/directors are scholar and judge-deciding the rules under which others will operate and then enforcing them. If they work amongst those governed by the rules, it will corrupt their moral duty to enforce the rule system. Wray-Bliss (2009) would likely frame this as an ethical rule to 'keep your distance' (from others). Based on the arguments of Shamir (1993) and Anthony (1998), we contend that this illustrates why Weberian ethics produces poor ethical outcomes-it is not sensitive or responsive to the moral dilemmas of practice.

The charitable model, therefore, is premised on one group of value holders/generators undertaking activities for others, ostensibly helping those unable to help themselves within a governance system that requires they keep their distance (Westall 2001). According to The Code Founding Group (2010) - a body representing Association of Chief Executives of Voluntary Organisations (ACEVO), Charity Trustee Network and National Council for Voluntary Organisations (NCVO) (amongst others) - the six principles for good charity governance are: (1) understand the role; (2) delivery of purpose; (3) work effectively as a team and individual; (4) control; (5) integrity; and (6) be open and accountable. These six characteristics align well with compliance/rubber stamp board theory (Cornforth 2003), where safeguarding (integrity), checking practice against rules (accountability) and ratifying decisions (control) are considered the role of the board. Not surprisingly, this commitment to formal rationality and the separation of board and executive led Spear et al. (2009) to conclude that these types of SEs tend to lack an enterprise culture. To the extent that philanthropic governance retains a Weberian commitment to formal rationality, it will likely incline its practitioners towards bureaucratic processes controlled by an elite (the trustee board). The commitment to formal rationality also represents an ethical position that social/charitable purpose(s) (particularly under statutory law) requires performance management against predetermined criteria, judged by a regulatory authority against charitable objects.

In CMEs, the member-owned, controlled and governed model can be aligned with Cornforth's (2003) democratic model (see Table 1). At the heart of this is a strong orientation towards relationships through open membership, inclusive/democratic governance, economic democracy, participatory management and-in its most radical implementations-wage solidarity. The dominant rationalities are social (in governance) and substantive (regarding the social, economic and cultural needs of members). The democratic ideology of CMEs is rooted in one-person, one-vote system that usurps the formal rationality envisaged by Weber by dissolving the divide between rule-makers and rule-followers. As members, the 'governed' make the rules by which 'to govern', as well as 'be' governed. This is not the case in charities and charitable foundations where rule-makers are appointed and do not experience the effects of their own rule making. (They make rules for others.)

Governance in CMEs is internalised because members of the organisation (whether workers or users) design 'closedloop' systems for electing their boards (Turnbull 2001). The ethical emphasis shifts to 'self-help' by affording members scope to vary their 'objects' in democratic assemblies. As they can set objects without reference to a higher authority, the orientation is towards substantive, not formal, rationality. However, democratic decision-making may still be subject to formally rationality at the level of process.

In SRBs, there are governance models aligned with Cornforth's 'Agency' model (Table 1). Cornforth states that in this model, the principal agent (the entrepreneur) has different interests to those that work in the organisation. Therefore, an element of control, compliance and monitoring goes on. Whilst the entrepreneur could enforce this through formally rational systems, their own ethics (rather than the ethics implied by statutory objects) shifts the decision-making process towards substantive rationality. Entrepreneurs give pragmatic consideration to their previous experience and make decisions based on their own value system (Coase 1937). As Ridley-Duff and Bull (2016) state, one element of SRBs is a focus on innovation, which is strongest in the US literature where the value propositions of social entrepreneurs are taken as the drivers of social change (Friedman and Desivilya 2010; Light 2008). This focus on innovation (particularly in the use of private sector financial instruments) is also a feature of Yunus's (2007) argument for 'social business'. Yunus sets out two hybrid 'types' that both have substantively rational goals (i.e. the elimination of poverty). Yunus's first type adopts the characteristics of an SRB in which there are locks on both assets and profits. Yunus argues vigorously for equity instruments and arrangements that enable investors to recover their investment. To this end, he sees a need for a social investment industry to make capital available and establish the metrics that social investors need to make judgements about which investments produce the greatest social returns (Nicholls 2010). Whilst there is scope for an investment industry driven by formally rationality, this mode of thinking is restricted to the way investment is provided, not the social goals of the entrepreneur (who continues to exercise substantive rationality consistent their own ethical commitments).

In summary, this section has brought together different conceptualisations of SE and elaborated how formal, substantive and social rationality are applied to organise and manage activities. We compared the conceptualisations in Table 1 to present enterprise orientations across three hybrid types of SE that align with particular trajectories, forms of incorporation, types of governance, management ideologies and historical foundations. We now switch attention to 
theorising the links between these ethical outputs (types of SE) and underlying ethical inputs (motivations to act).

\section{Motivations, Individual Actions and Organisational Ethos}

In this section, we link motivations to act (Fig. 2) with SE types (Table 1) and their linkages to different rationalities. A distinction can be made between the person who directs actions and the beneficiary of the actions that are directed. Individualist philosophy can vary between the presumed self-interest that underpins entrepreneurial action 'I'll direct my effort towards helping myself' and the willingness of self-interested individuals to join together and engage in collective action for self-benefit 'I'll help you to benefit myself' (Coase 1937; Parnell 2011; Smith 1937 [1776]). Whilst contemporary culture is replete with images of aggressive action by individual entrepreneurs (in popular programmes like The Apprentice), Parnell (2011, p. 8), the former CEO of the Plunkett Foundation, contends that action directed by self-interest can also be organised jointly: 'An important feature of the co-operative approach is its acceptance of people [who are] largely driven by self-interest. It also acknowledges that most people are unlikely to modify their self-centred behaviour without a sufficient incentive to do so [...]. Co-operation recognises that self-centred behaviour can be moderated when a more enlightened form of selfinterest takes account of the wider mutual interest'.

For Parnell, collectivism is not always motivated by altruistic intent (even if altruism is the outcome). Instead, collective action, and the desire to work with others co-operatively, can still be motivated by the desire for individualised benefits. Examples of this can be found in trade unionism and mutual insurance schemes where individuals join to protect themselves but concurrently protect others through regular subscriptions of financial capital that are paid out on the basis of need.

On altruistic action (i.e. actions that are motivated by a deliberate intent to help others, not the self), there is a range of underpinning logics from entrepreneurial self-directed action 'I'll direct my efforts towards helping others' to working under the direction of an institution or authority (such a charity or public body) seeking to create a public benefit 'I'll help you to benefit others' (see Fig. 2). However, our argument here is that few people exist at the extremes of these axes. Equity theory (Huseman et al. 1987; Kilbourne and O'Leary-Kelly 1994) posits that people prefer balanced benefits in which neither individuals nor social groups are over or under compensated for their efforts 'I'll help others without exploiting myself, and share any benefits received with others'.

The theoretical underpinnings of these positions are elaborated in Fig. 3. The two-by-two matrix is re-divided into three-by-three matrix with nine orientations. The first dimension (across the top) is theorised using Polanyi's work on modes of economic exchange: redistribution, reciprocity and market (Evers 1995; Nyssens 2006; Pestoff 1998; Polanyi 2001 [1944]; Roy 2015). Importantly, Pestoff (2005) suggests this 'welfare mix' encapsulates a diversity of hybrid logics (beyond mission and market) and considers the actors involved.

Redistributive actions seek to move resources from one setting to another in accordance with pre-agreed political and social priorities. This logic is used by governments, public authorities and charities that raise funds (or taxes) from one source and redistribute them to others who create public goods/services. Reciprocity, on the other hand, is grounded in the logic of mutual aid, whereby equitable contributions to, and drawings from, mutual funds
Fig. 3 Mapping ethical ethos against motivations

\section{Activities directed} by / towards others

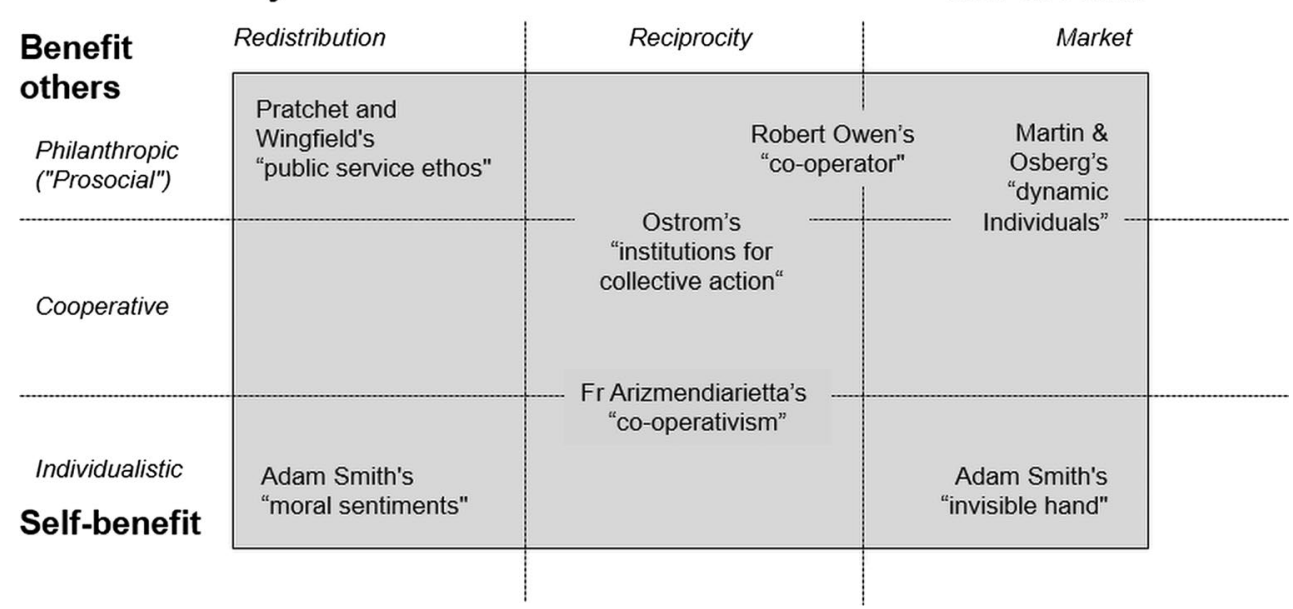


generate both individual and collective benefits (Ostrom et al. 1999; Restakis 2010). In this case, action is focused on securing reciprocal exchanges, counter gifts and cultivating a willingness amongst people with familial, kinship or community ties to proactively support each other's wellbeing. As Pestoff (2005) suggests, reciprocity is different to redistribution. Reciprocal action is conducted via a network of human relationships practising social rationality whilst redistributive action operates through a central authority pursuing formal (and perhaps also substantive) rationality.

The last type of economic exchange is through the market. Exchange is still the goal, but the mediating mechanism is no longer the social rationality of kinship, community ties or personal bonds. It is replaced by a depersonalised system of commodity production with buying and selling goods mediated by transaction costs that are variously inflated (by the seller) to increase the amount of profit or reduced (by the buyer) to minimise losses (Coase 1937). The more market transactions are for private benefit (i.e. a single goal of profit-maximisation or utility), the more they incline towards systems of substantive rationality (of the consumer) and formal rationality (of the financier). Where market transactions are for social benefit (i.e. intended to have a dual goal of wealth sharing and impact on the community), they will reorient towards social and substantive rationality.

The second axis (down the left-hand side) is theorised using works on social value orientation (the propensity and inclination of a person to help others). The concepts deployed here are drawn from studies of altruism rather than modes of economic exchange (Dreu and Boles 1998). The concepts distinguish a person who is individualistic (egocentric), co-operative or philanthropic (pro-social). The term individualistic is applied to a person who thinks only of their own benefit (egocentric), whereas the term philanthropic is applied to a person who thinks only of the benefit to others (pro-social).

What is the ethos behind each of the positions on the grid and the enterprise types in each space? As can be seen in Fig. 3, the top left space implies a public service ethos that guides philanthropic and redistributive action (Pratchett and Wingfield 1996). As we are concerned with SE, this orientation is omitted in the figures hereafter. In the opposite corner (bottom right, Figs. 3, 4) is a private enterprise ethos built on individualistic and market principles, outlined in Smith's 'The Wealth of Nations' (Smith 1937 [1776]). This orientation is also omitted from figures hereafter as this does not lead to SE either. That leaves an alternative dimension (starting bottom left, Fig. 3). Community action is redistributive, but with an individualistic ethos. In Smith's 'Moral Sentiments' (1790), he identifies the personal benefits of caring for others. Where the orientation is individualistic or co-operative, the enterprise orientations range from charitable associations (more pro-social) to community association, then to more personal benefits from collective action in trade and credit unions (Fig. 4). These can lead to SE organised as CTAs supported by a statutory or social framework of charitable objects. Formal rationality is still dominant, but can be moderated by social rationality.

In the opposite corner (top right, Fig. 3) is Martin and Osberg's (2007) idea of social entrepreneurs as 'dynamic individuals' with a market-based pro-social ethos. This orientation in social entrepreneurship leads to SE, particularly through SRBs (but including industrial and retail co-operatives as well as Yunus type 1 social businesses). In SRBs, social entrepreneurs are guided by their own, rather than a statutorily controlled set of social priorities, oriented towards pragmatism and substantial rationality. Where industrial co-operatives form or emerge (Owen 2014 [1816]), the social rationality of members starts to moderate
Fig. 4 Mapping enterprise orientations and forms
Activities directed by / towards others

Actions are self-directed

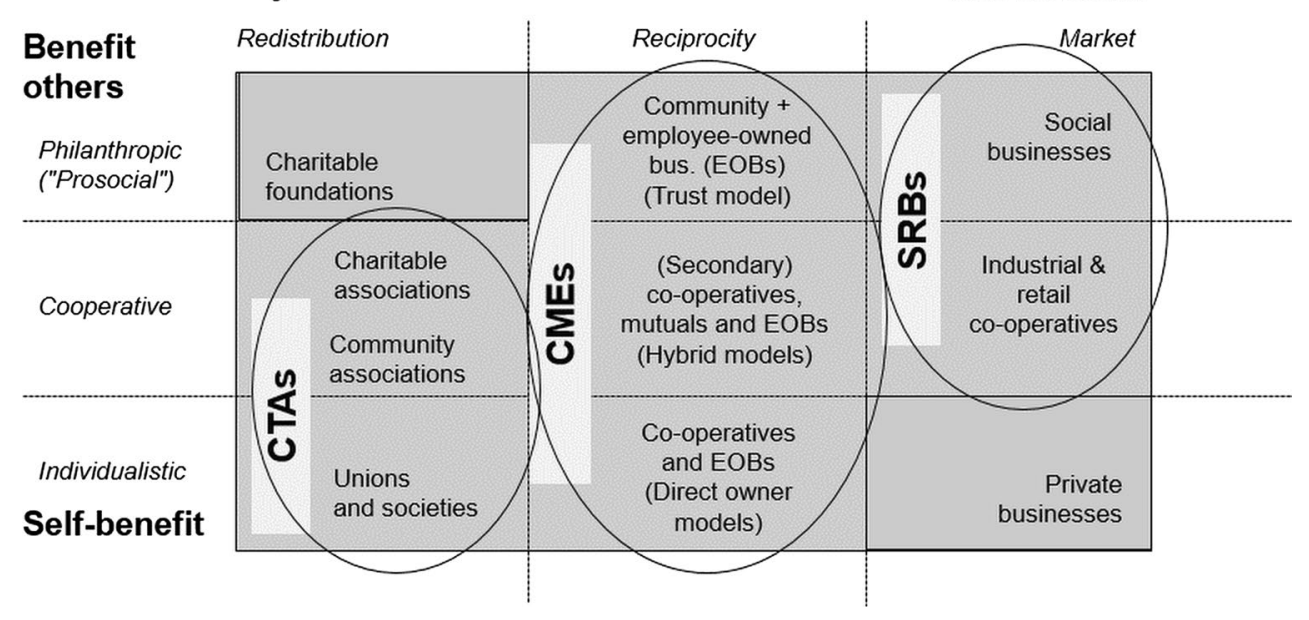


the substantive rationality of founders, and over time this will increase where governance systems yield power to a sovereign assembly of member-owners (see Whyte and Whyte 1991).

Lastly (Fig. 3, centre) is Ostrom's (1990) research on collective action based on the economics of reciprocity and co-operative social values. The orientation of co-operatives and mutual societies is based on the ethos of sharing benefits, not to keep them all to oneself or give them all away (Ridley-Duff 2007, 2008). The primary concern is productive social relations rather than 'objects' so the dominant rationality is social, rather than formal or substantive. The enterprise orientations that prevail here are co-operative societies, mutual enterprises, community businesses and member- or employee-led businesses (Fig. 4). There is a balance to be struck between community and individualistic orientations here, so Fig. 3 also shows Arizmendiarietta's co-operativism (Whyte and Whyte 1991), in which individual capital accounts exist alongside indivisible reserves within the Mondragon co-operative network in Spain.

In this section, we reflected on the philosophical motivations that guide individual and collective action. In mapping concepts, we linked motivations to act (inputs) against ethos (outputs) within a $3 \times 3$ matrix (Fig. 3 ). We now link our framework more firmly to enterprise orientations (Fig. 4) before identifying the ethical theories and rationalities that support each SE business model (Fig. 5).

\section{Switching the Axis-Ethical Theories of Philosophies of Action}

At this point, it is worth emphasising how our analysis is shaping our argument for an appreciation of ethics in the theorisation of SE. Figure 4 brings to the fore how enterprise orientations can be mapped onto motivations for individual and collective action. The dominant paradigm is one that sees the world through a lens that runs from the top left to the bottom right-public-social-private (showing a choice between a public service orientation, social and private economy). We posit that this runs from an altruistic communitarian ideology through to a neoliberal ideology (Fig. 5). Ethical theory in SE to date has principally been framed through this mission-market lens on the basis that SE arises out of the commercialisation of non-profits. As Figs. 4 and 5 show, this is crudely reductionist and fails to account for the diversity of motives, missions and legal forms in the field of SE.

SE is more than a single organisational and ethical type. By switching the framing, we offer another axis from bottom left to top right that shows three alternative hybrids (associative-cooperative-responsible) within the SE discourse (Figs. 4, 5). This exposes the 'deep back' and its multiple connections to ethical theory. On this alternative axis, the ideology is one of social liberalism (bottom left) through communitarian pluralism (middle) to pragmatic communitarianism (top right).

We now take each in turn. Social liberalism differs from neoliberalism through its greater emphasis on human, social and political (rather than economic) rights. Whilst the focus is still on the protection of individual rights and freedoms, the emphasis switches to freedoms beyond the marketplace-freedom of thought, speech and association. CTAs (Fig. 4, bottom left) seek to protect these by engaging in non-profit income generating activities that redistribute resources through associations and societies. Some altruistic action can be directed towards community benefit, maximising happiness for members and their host communities, and through economic exchanges that redistribute to those in greatest need, guided by utilitarian ethics (Fig. 5). Social liberalism may or may not have state support, but in either case it remains a vehicle for
Fig. 5 Mapping ethics within social enterprise groups

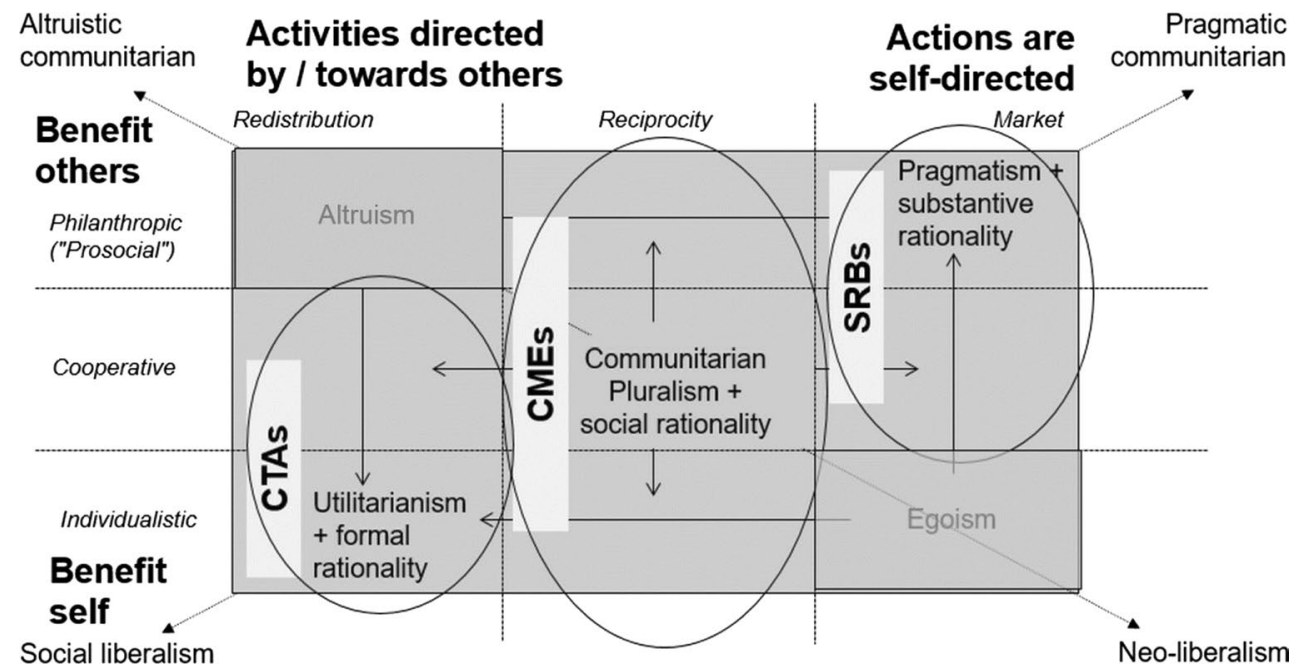


the redistribution and promotion of power, wealth and voice amongst a group of individuals. It can benefit from statutory support where this provides legal frameworks for its development. Social liberalism that is redistributive through either community or charitable associations still favours the formal rationality of charitable goals (Fig. 5), in which members commit to 'objects' and deploy a means-ends rationality to achieve them (Weber 1978). The legal and cultural frameworks here are charitable objects (under charity or non-profit law) or social objects (under community interest or community benefit society law).

A philosophy of communitarian pluralism leverages the power of individual freedom of thought, speech and association to reach collective agreements on mutual benefits for the members of a socio-economic enterprise (Ridley-Duff 2007). CMEs (Fig. 4, middle) incorporate their commitment to social rationality and mutual exchange through CMEs. The result intended (if not always fully realised) is an active inclusive democratic system of governance (Borzaga and Depredi 2014). These enterprises deploy both market and non-market trading strategies and can combine non-profit or for-profit principles to distribute benefits equitably to members and/or host communities. They combine memberownership and/or member-control with trading that provides a mix of member and public benefits. Within CMEs, pluralism is more fully realised in social and solidarity co-ops (Defourny and Nyssens 2016; Ridley-Duff 2015) because their structures are more open and inclusive than singlestakeholder co-ops and share benefits more widely across a community (Fig. 4). Thus, there are both unitary and pluralist forms of communitarianism (more unitary in worker/ consumer co-ops and more pluralist in multi-stakeholder coops that enfranchise workers, customers and investors/supporters). Hence, whilst the middle ground is fully realised by multi-stakeholder co-operativism, there are 'off-centre' forms that err towards more unitary governance logics (community businesses) or towards socially liberal forms of individual ownership (e.g. directly employee-owned businesses) (Fig. 4). Social rationality in CMEs is played out where members collectively decide on the benefits that matter at a particular point in time, and where the quality of human relationships (rather than charitable or social 'objects') is the dominant frame of reference (Fig. 5).

Social rationality (Ridley-Duff 2008), therefore, produces a different business model in which 'good' decision-making is measured and assessed in terms of member participation in determining objects that are relevant now, rather than fixed. Whilst there can be substantive rationality operating through a responsiveness to members and the community, where the social rationality of members dominates the substantive rationality of social entrepreneurs, there is a member and community orientation, rather than a market logic, dominating moral choices (Fig. 5).
Pragmatic communitarianism is more market-oriented and gives greater consideration to 'what works' in terms of utility and public benefit. SRBs (Fig. 4, top right) incorporate approaches to market exchange-based trading activities that proactively pursue sustainable development goals (Defourny and Nyssens 2016). Activities are self-directed by those seeking to bring about a public or community benefit. As SRBs, they are in a stronger position to take advantage of existing market institutions and its ideological rules. It leads to business models under the control of a single (or small group of) social entrepreneurs who purport to help others. Whilst utilitarian ethics (the best outcome for the greatest number of people) may prevail, this is a more pragmatic form of communitarianism driven by change makers and social activists (Yunus 2007). The arbiters of social value are social entrepreneurs operating in a community context, and it is their moral choices that are favoured, rather than those democratically agreed in an association or co-operative. As a result, the dominant rationality is substantive, rather than social or formal (Fig. 5).

In our central column of CMEs, different rationalities can be combined, but the ethical rules for establishing and operating collective SEs are premised on social rationality as an end it itself. In CTAs and SRBs, social rationality is the means (i.e. relationships between people are organised to pursue a social outcome or secure a financial profit). In contrast, within CMEs purpose is the means, (i.e. the purpose is chosen to (re)build a community of people). This aligns with previous research evidence that it does not matter what a company/enterprise does so long as the result is a cohesive community that advances human well-being (Laville and Nyssens 2001; Ridley-Duff 2015). As ScottCato et al. (2008) argued, academic debate on the definition of the social economy depends on organising principles, not on the purpose(s) or market in which the enterprise operates.

To summarise, we have achieved our objective of critically analysing entrepreneurial intentions in SE from an alternative perspective. We now turn our attention to the research question and our contribution. In our conclusions, we address the question 'How can a critical analysis of entrepreneurial intention inform an appreciation of ethics in social enterprise business models?'.

\section{Conclusions}

We present social enterprise ethics as the rule systems that emerge from social entrepreneurial choices to hybridise redistribution, reciprocity and market exchange in pursuit of pro-social, mutualised and individualised outcomes. This challenges the dominant conceptualisation of SE as a hybrid blend of mission and market dichotomy (purpose-versusresource) by reframing hybridity in terms of the moral 
choice of economic system (redistribution, reciprocity and market) and social value orientation (personal, mutual or public benefit). We have deconstructed the political foundations, ethical commitments and outcomes of CTAs, CMEs and SRBs by examining the rationalities (formal, social and substantive) that underpin them, and interpreted how this affects the way moral choices are enacted and enforced. Whilst conceptual modelling of SE is not new, this paper contributes to knowledge by developing a theory of social enterprise ethics based on the moral/political choices that are made by entrepreneurs (knowingly and unknowingly) when choosing between systems of economic exchange, legal form and social value orientation.

Having reviewed the literature and looked at the distinctions between SE hybrid forms (Alter 2007; Conaty 2001; Cornforth 2003; Dees 1998; Westall 2001), we draw on conceptual models that grapple with SE identities (community interest companies, trading charities, co-operatives, mutuals, community benefit societies). We argue that the framing of hybridity to date only addresses the 'ethical front' of SE-its rhetorical appeal. Our paper offers a substantive analysis of new thinking on hybridisation linked to alternative framings of the field to explore its 'deep back' (Bull 2015; Defourny and Nyssens 2016; Ridley-Duff and Bull 2016). We paid attention to the different framing of means and ends that occurs when social rationality dominates moral choices in the context of cooperative action. We clarify the moral choices made when configuring a SE by pinpointing ethical differences between hybrids. We pinpoint the foundations of different enterprise orientations, moving the debate on SE away from a public-private dichotomy to one that builds an alternative perspective rooted in associative, cooperative and responsible social entrepreneurship.

Firstly, having considered current conceptualisations of SE we outline the differences between types at the level of ethical inputs and outputs. Secondly, we highlight significant differences between the rationalities and ethical commitments and bring them together into a coherent meta-theory. This paper fills a void by drawing together prior research on spectrum models to highlight the swing from philanthropic to commercial enterprise orientations and business models. We build on this in our third contribution by creating a matrix to support our argument that switching from a publicsocial-private mindset to one based on associative-cooperative-responsible practices better captures the rationalities and ethical propositions of different orientations in SE.

We have responded to Ogbor's $(2000$, p. 620) challenge to question; 'how and why particular ideational systems, institutions and belief systems produce and shape the pattern of entrepreneurship in contemporary society'. We did this by opening up a different axis of thought that ranges from socially liberal forms of charitable and community association, undertaking CTAs, through more pluralist forms of cooperation and mutuality in CMEs, to the pragmatic communitarianism of 'dynamic' social entrepreneurs in SRBs. We also acknowledge and build on the scholarly contributions from Copenhagen Business School (see Barinaga 2013; Hjorth 2013) by connecting rationalities to entrepreneurial intentions and legal form, then opening the space for a greater consideration of the 'social' in public entrepreneurship and entrepreneurial discourses. Our theory links to and explicates how alternatives to the dominant public/private (mission-market) discourse are rooted in collectivist, participatory and activist traditions of (social) enterprise creation (Daskalaki et al. 2015). We offer a theory of the way motivations drive individual and collective action, change the way we respond to the social challenges of meeting our needs, satisfying our wants and advancing practice, and thereby produce distinctive systems of social enterprise ethics.

\section{Compliance with Ethical Standards}

Conflict of interest Authors declare that they have no conflict of interest.

Human and animal rights This article does not contain any studies with human participants or animals performed by any of the authors.

Open Access This article is distributed under the terms of the Creative Commons Attribution 4.0 International License (http://creativeco mmons.org/licenses/by/4.0/), which permits unrestricted use, distribution, and reproduction in any medium, provided you give appropriate credit to the original author(s) and the source, provide a link to the Creative Commons license, and indicate if changes were made.

\section{References}

Alter, K. (2007). Social enterprise typology. (Version 1.5), virtue ventures. www.virtueventure.com/typology. Accessed Oct 2016.

Amin, A., Cameron, A., \& Hudson, R. (1999). Welfare as work? The potential of the UK social economy. Environment and Planning, 31, 2033-2051.

Anthony, P. (1998). Management education: Ethics vs morality. In M. Parker (Ed.), Ethics and organization (pp. 269-281). London: Sage Publications.

Barinaga, E. (2013). Politicising social entrepreneurship-three social entrepreneurial rationalities towards social change. Journal of Social Entrepreneurship, 4(3), 347-372.

Billis, D. (2010). Towards a theory of hybrid organizations. In D. Billis (Ed.), Hybrid organizations and the third sector (pp. 46-69). Basingstoke: Palgrave Macmillan.

Birchall, J. (2012). A 'member-owned business' approach to the classification of co-operatives and mutuals. In D. McDonnell \& E. C. McKnight (Eds.), The co-operative model in practice: International perspectives (pp. 67-82). Aberdeen: University of Aberdeen.

Borzaga, C., \& Depredi, S. (2014). When social enterprises do it better: Efficiency and efficacy of work integration in Italian social co-operatives. In S. Denny \& F. Seddon (Eds.), Social enterprise: 
Accountability and evaluation around the world (pp. 85-101). London: Routledge.

Brown, J. (2004). Co-operative capital: A new approach to investment in co-operatives and other forms of social enterprise. Cooperative Action: Manchester.

Brown, J. (2006). Designing equity finance for social enterprises. Social Enterprise Journal, 2(1), 73-81.

Bull, M. (2015). Shape sorting: Towards defining social enterprise in the UK. International Social Innovation Research Conference, New York.

Bull, M., Ridley-Duff, R., Foster, D., \& Seanor, P. (2010). Defining social enterprise through a theoretical conceptualisation of ethical capital. Social Enterprise Journal, 6(3), 250-264.

Carroll, A. (1991). The pyramid of corporate social responsibility: Toward the moral management of organizational stakeholders. Business Horizons, 34, 39-48.

Chell, E., Spence, L., Perrini, F., \& Harris, J. (2016). Social entrepreneurship and business ethics: Does social equal ethical? Journal of Business Ethics, 133(4), 619-625.

Coase, R. (1937). The nature of the firm. Economica, 4, 386-405.

Conaty, P. (2001). Homeopathic finance-Equitable capital for social enterprises. London: New Economics Foundation.

Cornforth, C. (2003). Introduction: The changing context of governance-Emerging issues and paradoxes. In C. Cornforth (Ed.), The governance of public and non-profit organizations: What do boards do?. London: Routledge.

Costa, A., \& Saraiva, L. (2012). Hegemonic discourses on entrepreneurship as an ideological mechanism for the reproduction of capital. Organization, 19(5), 587-614.

Dacin, P., Dacin, M., \& Matear, M. (2010). Social entrepreneurship: Why we don't need a new theory and how we move forward from here. Academy of Management Perspectives, 24(3), 37-57.

Dacin, M., Dacin, P., \& Tracey, P. (2011). Social entrepreneurship: A critique and future directions. Organization Science, 22(5), 1203-1213.

Dart, R. (2004). The legitimacy of social enterprise. Nonprofit Management and Leadership, 14(4), 411-424.

Daskalaki, M., Hjorth, D., \& Mair, J. (2015). Are entrepreneurship, communities and social transformation related? Journal of Management Inquiry, 24(4), 419-423.

Davies, I. A., \& Crane, A. (2010). CSR in SMEs: Investigating employee engagement in fair trade companies. Business Ethics: A European Review, 19(20), 126-139.

Davies, I. A., Doherty, B., \& Knox, S. (2010). The rise and stall of a fair trade pioneer: The story of Cafédirect. Journal of Business Ethics, 92(1), 127-147.

Dees, G. (1998). Enterprising non-profits: What do you do when traditional sources of funding fall short? Harvard Business Review, $76,54-67$.

Defourny, J., \& Nyssens, M. (2010). Conceptions of social enterprise and social entrepreneurship in Europe and the United States: Convergences and divergences. Journal of Social Entrepreneurship, $1(1), 32-53$.

Defourny, J., \& Nyssens, M. (2016). Fundamentals for an international typology of social enterprise models. ICSEM Working Papers, No. 33, Liege. The International Comparative Social Enterprise Models (ICSEM) Project.

Dey, P., \& Steyaert, C. (2010). The politics of narrating social entrepreneurship. Journal of Enterprising Communities, People and Places in the Global Economy, 4(1), 85-108.

Dey, P., \& Steyaert, C. (2016). Rethinking the space of ethics in social entrepreneurship: Power, subjectivity, and practices of freedom. Journal of Business Ethics, 133(4), 627-641.

Doherty, B., \& Davies, I. (2013). Where next for fair trade? Business History, 55(2), 161-189.
Dreu, C., \& Boles, T. (1998). Share and share alike or winner takes all? Organization Behavior and Human Decision Processes, 76(3), 253-276.

DTI (2002). Social enterprise: A strategy for success. www.sbs.gov. uk/content/socialenterprise/documents.pdf. Accessed Oct 2003.

Evers, A. (1995). Part of the welfare mix: The third sector as an intermediate area. VOLUNTAS: International Journal of Voluntary and Nonprofit Organizations, 6(2), 119-139.

Feldman, S. (1991). An interpretation of max Weber's theory of law: Metaphysics, economics and the iron cage of constitutional law. Law and Social Inquiry, 16, 205-248.

Fisher, C., \& Lovell, A. (2006). Business ethics and values. Harlow, England: Prentice Hall.

Friedman, M. (1970/1993). The social responsibility of business is to increase its profits. The New York Times Sunday Magazine, September 13. Reprinted in Jennings, M. M. (2003). Business ethics (4th ed., pp. 41-46). Mason: Thomson.

Friedman, V., \& Desivilya, H. (2010). Integrating social entrepreneurship and conflict engagement for regional development in divided societies. Entrepreneurship and Regional Development, $22(6), 495-514$.

Haack, S. (1976). The pragmatist theory of truth. The British Journal for the Philosophy of Science, 27, 231-249.

Hjorth, J. (2013). Public entrepreneurship: Desiring social change, creating sociality. Entrepreneurship and Regional Development, 25(1-2), 34-51.

Huseman, R., Hatfield, J., \& Miles, E. (1987). A new perspective on equity theory: The equity sensitivity construct. Academy of Management Review, 12(2), 222-234.

Kilbourne, L., \& O'Leary-Kelly, A. (1994). A re-evaluation of equity theory: The influence of culture. Journal of Management Inquiry, 3(2), 177-188.

Laasch, O., \& Conway, R. (2015). Principles of responsible management. New York: Cengage Learning.

Laville, J., \& Nyssens, M. (2001). Towards a theoretical socio-economic approach. In C. Borzaga \& J. Defourny (Eds.), The emergence of social enterprise (pp. 312-332). Routledge: London.

Light, P. (2008). The search for social entrepreneurship. Washington, DC: Brookings Institution Press.

Mair, J., \& Marti, I. (2006). Social entrepreneurship research: A source of explanation, prediction and delight. Journal of World Business, 41(1), 36-44.

Martin, R., \& Osberg, S. (2007). Social entrepreneurship: The case for definition. Stanford Social Innovation Review, 5, 29-39.

Mason, C., \& Doherty, B. (2015). A fair trade-off? Paradoxes in the governance of fair-trade social enterprises. Journal of Business Ethics, 136(3), 451-469.

Murdoch, A. (2007). No man's land or promised land? Social Enterprise Research Conference, London South Bank University.

Nicholls, A. (2006). Social entrepreneurship: New models of sustainable social change. Oxford: Oxford University Press.

Nicholls, A. (2010). The institutionalization of social investment: The interplay of investment logics and investor rationalities. Journal of Social Entrepreneurship, 1(1), 70-100.

Nyssens, M. (2006). Social enterprise at the crossroads of market, public and civil society. London: Routledge.

Ogbor, J. (2000). Mythicizing and reification in entrepreneurial discourse: Ideology-critique of entrepreneurial studies. Journal of Management Studies, 37(5), 605-635.

Ostrom, E. (1990). Governing the commons: The evolution of institutions for collective action. Cambridge: Cambridge University Press.

Ostrom, E., Burger, J., Field, C. B., Norgaard, R. B., \& Policansky, D. (1999). Revisiting the commons: Local lessons, global challenges. Science, 284, 278-282. 
Owen, R. (2014) [1816]. A new view of society. Kindle Edition ed. s.l. Gold Books.

Parker, M. (1998a). Ethics and organizations. London: Sage Publications.

Parker, M. (1998b). Introduction: Ethics, the very idea? In M. Parker (Ed.), Ethics and organizations (pp. 1-14). London: Sage Publications.

Parker, M., \& Thomas, R. (2011). What is a critical journal? Organization, 18(4), 419-427.

Parnell, E. (2011). Co-operation: The Beautiful Idea. Los Gatos: Smashwords.

Pearce, J. (2003). Social enterprise in anytown. London: Calouste Gulbenkian Foundation.

Pestoff, V. (1998). Beyond the market and state: Social enterprises and civil democracy in a welfare state. Aldershot: Ashgate.

Pestoff, V. (2005). Democratizing the welfare state: Revisiting the third sector in democratic and welfare theory. Sundsvall: Mid-Sweden University.

Polanyi, K. (2001) [1944]. The great transformation: The political and economic origins of our time. Boston: Beacon.

Pratchett, L., \& Wingfield, M. (1996). Petty bureaucracy and wooly minded liberalism? The changing ethos of local government officers. Public Administration, 74, 639-656.

Restakis, J. (2010). Humanizing the economy: Cooperatives in the age of capital. Gabroila Island: New Society Publishers.

Rhodes, C., Pullen, A., \& Clegg, S. (2010a). If I should fall from grace: Stories of change and organizational ethics. Journal of Business Ethics, 91(4), 535-551.

Rhodes, C., Pullen, A., \& Clegg, S. (2010b). If I should fall from grace: Stories of change and organizational ethics. Journal of Business Ethics, 91(4), 535-551.

Ridley-Duff, R. (2007). Communitarian perspectives on social enterprise. Corporate Governance: An International Review, 15(2), 382-392.

Ridley-Duff, R. (2008). Social enterprise as a socially rational business. International Journal of Entrepreneurial Behaviour and Research, 14(5), 291-312.

Ridley-Duff, R. (2015). The case for fairshares: A new model for social enterprise development and the strengthening of the social and solidarity economy. Charleston: CreateSpace Independent Publishing.

Ridley-Duff, R., \& Bull, M. (2016). Understanding social enterprise: Theory and practice (2nd ed.). London: Sage Publications.

Ridley-Duff, R., \& Southcombe, C. (2012). The social enterprise mark: A critical review of its conceptual dimensions. Social Enterprise Journal, 8(3), 178-200.

Roberts, J. (2003). The manufacture of corporate social responsibility: Constructing corporate sensibility. Organization, 10(2), 249-265.

Roy, M. (2015). Conceptualizing social enterprise as a public health intervention. Unpublished Ph.D. Glasgow: Caledonian University.

Scott-Cato, M., Arthur, L., Keenoy, T., \& Smith, J. (2008). Entrepreneurial energy: Associative entrepreneurship in the renewable energy sector. International Journal of Entrepreneurial Behaviour and Research, 14(5), 313-329.
Selznick, P. (1992). The moral commonwealth: Social theory and the promise of community. Berkeley: University of California Press.

Seward Community Co-operative. www.seward.coop/about. Accessed Oct 2017.

Shamir, R. (1993). Formal and substantive rationality in America Law: A Weberian perspective. Social and Legal Studies, 2, 45-72.

Simons, H. (1978). From substantive to procedural rationality. In T. Kastelein et al. (Eds.), 25 Years of economic theory: Retrospect and prospect (pp. 65-88). New York: Springer.

Smith, A. (1790). The theory of moral sentiments. Sao Paulo: Metalibri.

Smith, A. (1937) [1776]. An inquiry into the nature and causes of the wealth of nations. New York: The Modern Library.

Somers, A. (2013). The emergence of social enterprise policy in New Labour's second term. Available at: http://research.gold. ac.uk/8051/1/POL thesis Somers 2013.pdf. Accessed Jan, 8 2015.

Spear, R., Cornforth, C., \& Aiken, M. (2009). The governance challenges of social enterprises: Evidence from a UK empirical study. Annals of Public and Cooperative Economics, 80(2), 247-273.

Steyaert, C., \& Hjorth, D. (2005). Narrative and discourse approaches in entrepreneurship: A second movements in entrepreneurship. Cheltenham: Edward Elgar.

Teasdale, S. (2012). What's in a name? Making sense of social enterprise discourses. Public Policy and Administration, 27(2), 99-119.

Tedmanson, D., Verduyn, K., Essers, C., \& Gartner, W. (2012). Critical perspectives in entrepreneurship research. Organization, 19(5), 531-541.

The Code Founding Group. (2010). www.governancecode.org/fullcode-of-governance/. Accessed Oct 2010.

Turnbull, S. (2001). A new way to govern. London: New Economics Foundation.

Wagner-Tsukamoto, S. (2005). An economic approach to business ethics: Moral agency of the firm and the enabling and constraining effects of economic institutions and interactions in a market economy. Journal of Business Ethics, 60(1), 75-89.

Wagner-Tsukamoto, S. (2007). Moral agency, profits and the firm: Economic revisions to the Friedman theorem. Journal of Business Ethics, 70(2), 209-220.

Weber, M. (1978). Economy and society. Berkley: University of California Press. (Originally published 1956).

Westall, A. (2001). Value-led, market-driven: Social enterprise solutions to public policy goals. London: IPPR.

Whyte, W., \& Whyte, K. (1991). Making Mondragón: The growth and dynamics of the worker cooperative complex ( 2 nd ed.). New York: Cornell University Press.

Wray-Bliss, E. (2009). Ethics: Critique, ambivalence, and infinite responsibilities (unmet). In M. Alvesson, T. Bridgman, \& H. Willmott (Eds.), The oxford handbook of critical management studies (pp. 267-285). Oxford: Oxford University Press.

Yunus, M. (2007). Creating a world without poverty: Social business and the future of capitalism (Kindle ed.). New York: Public Affairs. 